\title{
ANALISA DATA VIBRASI UNTUK KLASIFIKASI KERUSAKAN KOMPRESSOR TURBIN GAS PADA PT. PLN SEKTOR PEMBANGKITAN BELAWAN
}

\author{
Hery E.Permana ${ }^{1 *}$, Ikhwansyah Isranuri ${ }^{2}$, M. Sabri ${ }^{3}$, Mahadi $^{4}$, Dian M. Nasution ${ }^{5}$ \\ 1,2,3,4,5 Departemen Teknik Mesin ,Fakultas Teknik ,Universitas Sumatera Utara \\ E-Mail : heryeggiapermana@ hotmail.co.id
}

\begin{abstract}
ABSTRAK
Teknik perawatan secara prediktif banyak diaplikasikan di dunia industri yang salah satunya adalah untuk komponen mesin berputar. Teknik perawatan ini dapat mendeteksi jenis kerusakan pada suatu mesin tanpa menghentikan operasi mesin tersebut dengan cara analisis getaran melalui identifikasi terhadap sinyal getaran yang dihasilkan. Dalam penelitian ini akan dianalisis sinyal getaran yang dibangkitkan oleh keadaan terkini mesin melalui pengambilan data sinyal getaran pada arah radial (horizontal) pada kompressor turbin gas . Dari hasil analisis sinyal getaran, dapat diketahui jenis dan besarnya tingkat getaran yang dibangkitkan dalam interval waktu oleh kelonggaran melalui perbandingan nilai getaran terhadap trending dan dengan standar yang berlaku memperlihatkan amplitudo tinggi pada kompressor horizontal ,vertical dan aksial kondisi getaran sebesar 11 mm/s, berdasarkan standar ISO 10816.
\end{abstract}

Kata Kunci : Perawatan, Analisis Getaran, Vibrasi

\begin{abstract}
Predictive maintenance techniques are widely applied in the industrial world, one of which is for rotating machine components. This maintenance technique can detect the type of damage to a machine without stopping the operation of the engine by means of vibration analysis through identification of the vibration signals produced. In this Final Project will be analyzed the vibration signals generated by the current state of the engine through vibration signal data retrieval in the radial direction (horizontal) on the gas turbine compressor. From the results of vibration signal analysis, it can be seen the type and magnitude of the level of vibration generated in the time interval by leeway through the comparison of vibration values to trending and with applicable standards show high amplitude in horizontal, vertical and axial compressor conditions of vibration of $11 \mathrm{~mm} / \mathrm{s}$, based on ISO 10816 standard.
\end{abstract}

Keywords: Treatment, Vibration Analysis, Vibrations 


\section{Pendahuluan}

Pemeliharaan (maintenance) berperan penting dalam kegiatan produksi dari suatu perusahaan yang menyangkut kelancaran atau kemacetan produksi, volume produksi, serta agar produk dapat diproduksi dan diterima konsumen tepat pada waktunya (tidak terlambat) dan menjaga agar tidak terdapat sumber daya kerja yang menganggur karena kerusakan (downtime) pada mesin sewaktu proses produksi sehingga dapat meminimalkan biaya kehilangan produksi atau bila mungkin biaya tersebut dapat dihilangkan.

Pemeliharaan yang baik akan mengakibatkan kinerja perusahaan meningkat, kebutuhan konsumen dapat terpengaruhi tepat waktu, serta nilai investasi yang dialokasikan untuk peralatan dan mesin dapat diminimalkan. Selain itu pemeliharaan yang baik juga dapat meningkatkan kualitas produk yang dihasilkan dan mengurangi waste yang berarti mengurangi ongkos produksi.

\section{Pengumpulan Data}

Data yang digunakan adalah data hasil pengukuran vibration velocity titik 2 dan titik 3 dari turbin gas PT.PLN Persero pembangkit belawan. Data diukur oleh bagian predictive maintenance

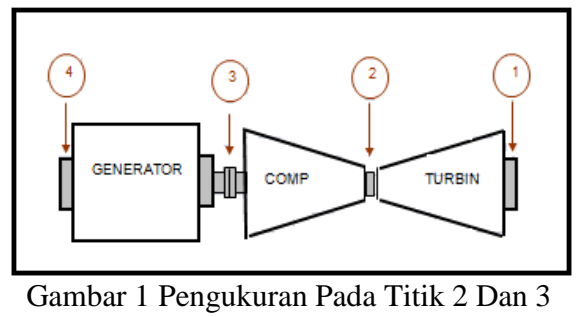

\section{Standar Analisa}

Dalam mengindentifikasi berbagai macam kerusakan pada mesin yang dianalisis berdasarkan getarannya , maka kita menggunakan ISO 10186 dan ISO 2372 dalam prosesnya.

ISO 10186 hanya terbatas untuk memberi standar standar yang baku untuk sebuah velocity getaran yang bersifat merusak mesin, namun tidak mampu untuk dijadikan acuan dalam mengidentifikasi kerusakan yang terjadi. Untuk itu kita menggunakan ISO 2372 untuk mengidentifikasi kerusakan yang terjadi pada mesin.

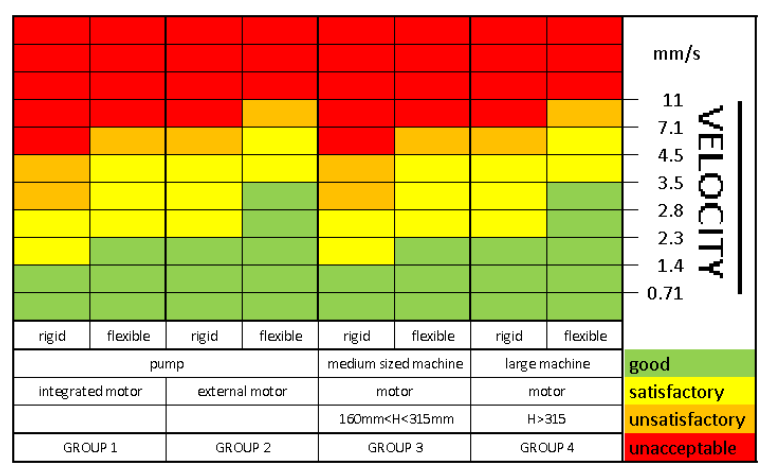

Gambar 2. ISO 10186 


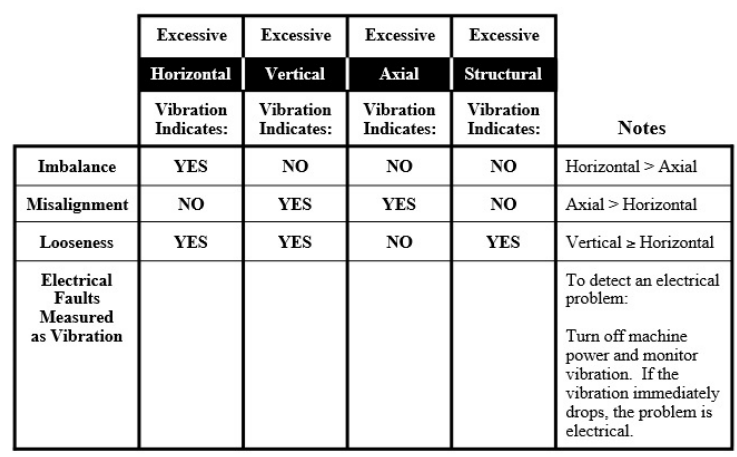

Gambar 3. ISO 2372

\section{Mechanical failure}

\section{a.Misalignment}

Misalignment adalah suatu kondisi pada sistem poros-kopling ketika dua sumbu poros yang terhubung tidak berada dalam satu garis sumbu. Misalignment merupakan penyebab utama terjadinya getaran selain dari unbalance (M. Bur, M. Okuma,2005).

\section{b.Looseness}

Looseness atau yang biasa disebut mechanical looseness (Kelonggaran mekanik) adalah salah satu jenis kerusakan pada mesin yang menyebabkan terjadinya getaran. Kelonggaran mekanik dapat terjadi apabila tutup bantalan longgar atau ikatan mesin ke pondasi tidak kuat. Gejala kerusakan ini ditandai dengan adanya frekuensi getaran dominan pada $1 \frac{1}{2}, 1,1 \frac{1}{2}, 2$, dst $\mathrm{x}$ rpm atau $\mathrm{n} \times \mathrm{rpm}$ pada domain frekuensinya (V.Wowk,1991).

\section{C.Unbalance}

Unbalance adalah suatu kondisi dimana pusat massa rotor tidak berimpit dengan pusat massa poros, sehingga ketika elemen ini berputar akan menimbulkan gaya sentrifugal. Gaya sentrifugal meng-eksitasi sistem selama sistem berputar, sehingga menimbulkan getaran. Unbalance bisa disebabkan oleh penyebaran massa rotor yang tidak merata atau pemasangan poros yang tidak tepat pada pusatnya . Pada Rotor turbin, unbalance juga bisa disebabkan oleh sudut-sudunya yang terkikis akibat pengikisan oleh fluida.

\section{d.Bearing defect}

Bantalan adalah komponen yang kritis pada mesin rotasi karena bertugas sebagai tumpuan beban. Penelitian secara berkelanjutan dilakukan untuk menghitung umur bantalan dengan beberapa faktor ketelitian, sehingga mampu mengetahui umur bantalan dan umur dengan lebih akurat (Fariha et al, 2008). Tetapi, bantalan tidak berumur sesuai dengan perhitungan.

Fatique di permukaan bantalan terjadi sehingga membatasi kelayakan bantalan beroperasi (Kapidzic et al., 2015). Pada umumnya kegagalan disebabkan kerusakan permukaan bantalan berupa micro-pitting, smearing, indentation, deformasi plastis dan korosi. Akibatnya bantalan mengalami 
kegagalan dan mesin mengalami kerusakan (breakdown) secara mendadak (Purnama dan Ariosuko, 2014).

\section{Hasil Analisa}

\section{a.Time and frequency domain plotting}

Data yang dikumpulkan diplot menjadi grafik berdomain waktu, dari grafik kita akan mengetahui waktu waktu tertentu dimana compressor mengalami getaran yang merusak ataupun sebaliknya ketika getaran kompresor masih dalam batas yang dapat ditoleransi.

Pengukuran dan plotting grafik dilakukan pada 3 sumbu di tiap titik yang ada. Plotting grafik dapat dilihat pada gambar di bawah.

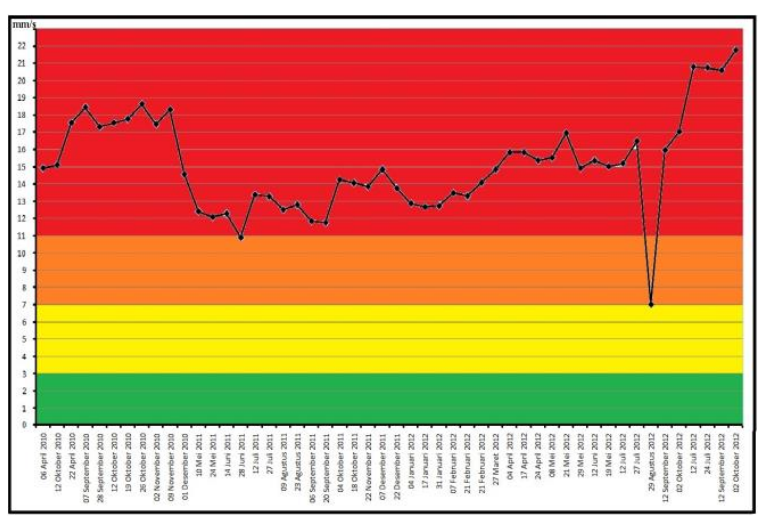

Gambar 4. Time Domain Titik 2 Sumbu Horizontal

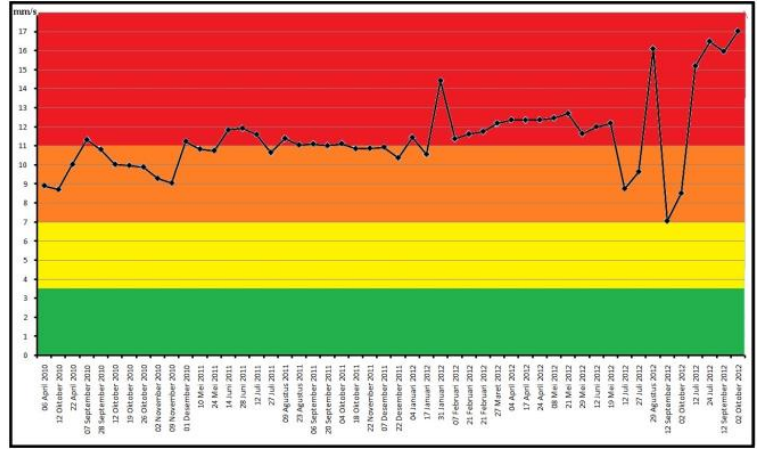

Gambar5. Time Domain Titik 2 Sumbu Vertikal

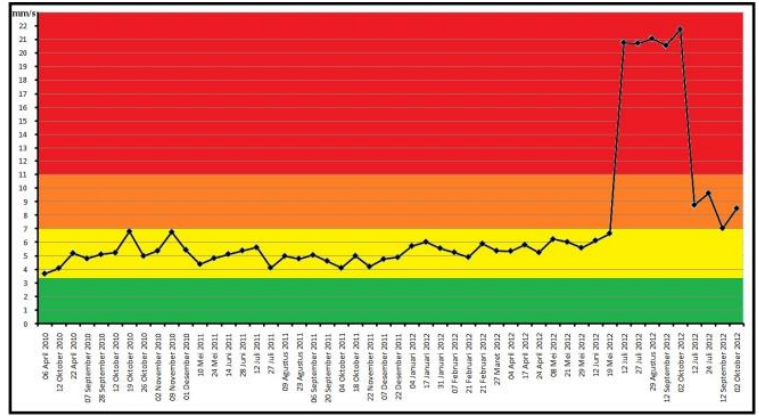

Gambar 6. Time Domain Titik 2 Sumbu Axial 


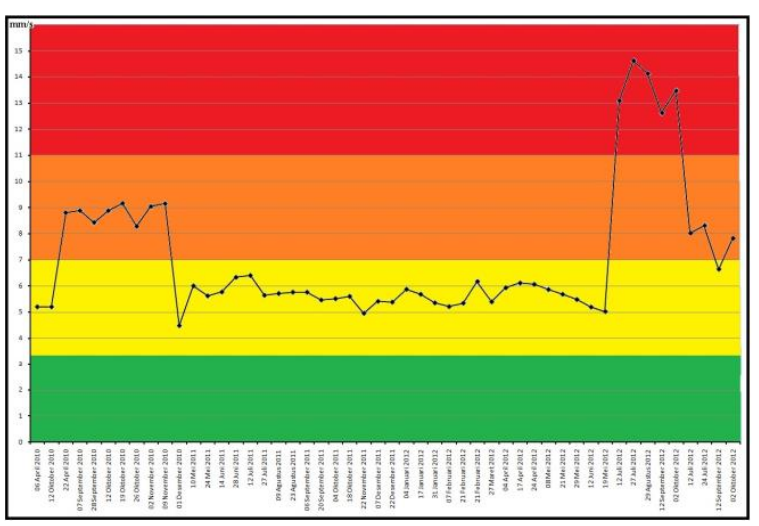

Gambar 7. Time Domain Titik 3 Sumbu Horizontal

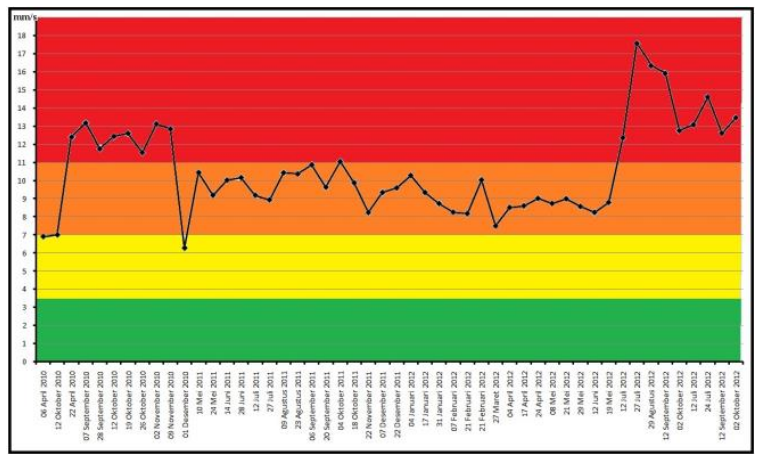

Gambar 8. Time Domain Titik 3 Sumbu Vertikal

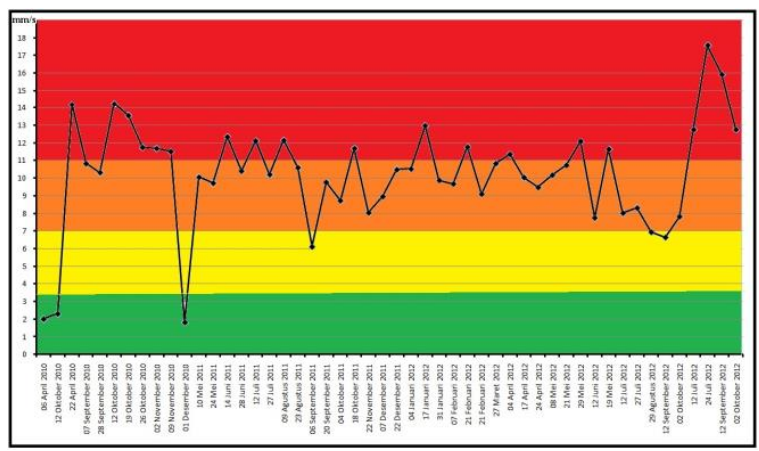

Gambar 9. Time Domain Titik 3 Sumbu Axial

Setelah mendapatkan grafik dengan domain waktu, data di plot menjadi grafik frequency domain. Data plotting frequency domain didapat dari pengolahan data menggunakan Ms.Excel > Data $>$ Data Analysis>Fourrier Analysis

Data yang dihasilkan adalah data imaginary number ,data ini diolah dengan fungsi (imabs:number:number) sehingga dihasilkan angka rill yang dapat diplot menjadi grafik dengan frequency domain.

Hasil daripada data frequency domain dapat dilihat pada gambar dibawah 


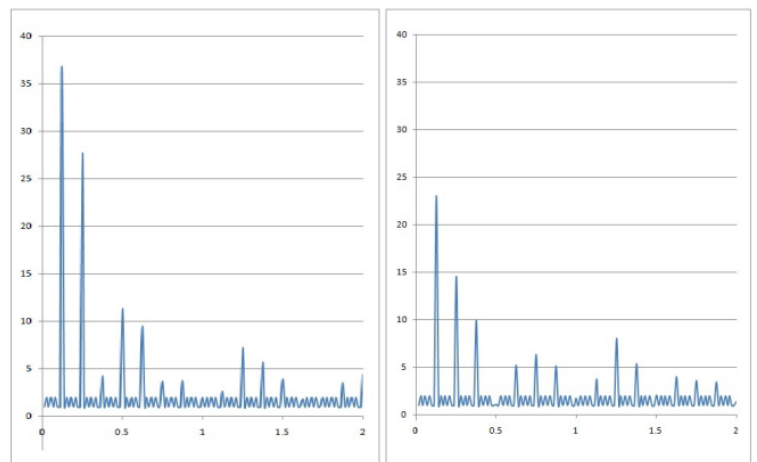

Gambar 10. Perbandingan Frequency Domain Titik 2 Dan Titik 3 Sumbu Horizontal

Pada titik 2 dan 3 terdapat velocity tinggi pada frequency yang rendah, namun semakin tinggi nilai frequencynya tingkat velocity getaran juga ikut turun . hal ini adalah hal dini yang menandakan adalah gejala kerusakan pada titik 2 dan 3

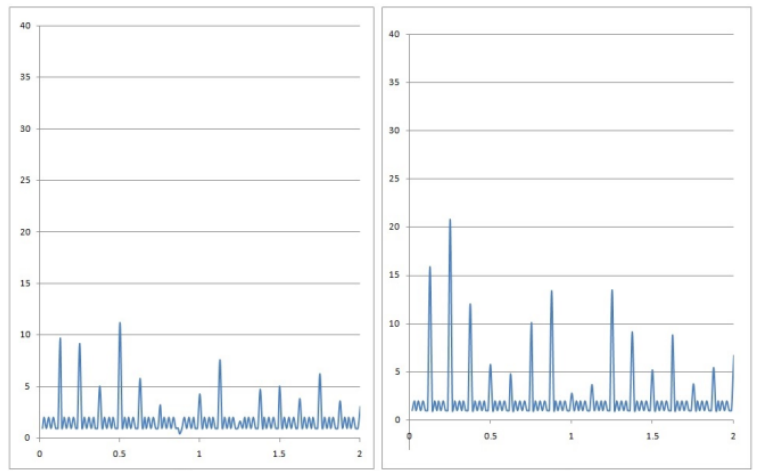

Gambar 11. Perbandingan Frequency Domain Titik 2 Dan Titik 3 Sumbu Horizontal

Pada sumbu vertical persebaran velocity titik 2 lebih merata daripada titik 3 . Titik 3 konsisten dengan velocity getaran tinggi pada domain frequency.

Melalui sumbu vertical kita mendapatkan indikasi bahwa titik 2 dan titik 3 memiliki jenis kerusakan yang berbeda atau memiliki tingkat kerusakan yang berbeda.

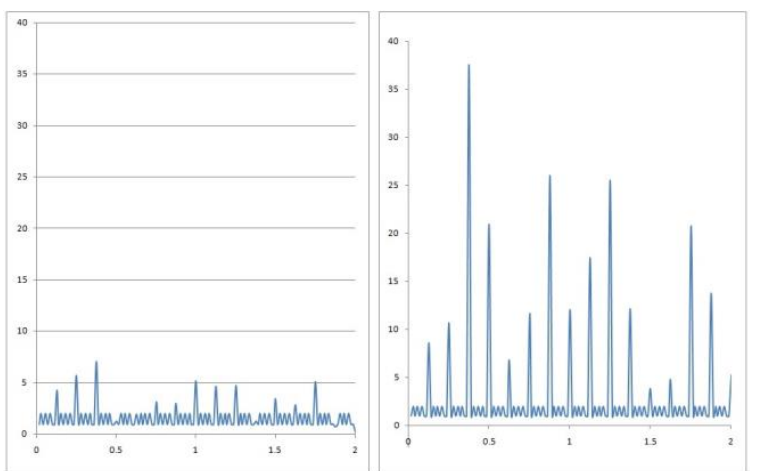

Gambar 12. Perbandingan Frequency Domain Titik 2 Dan Titik 3 Sumbu Horizontal

Grafik Sumbu axial menunjukkan perbedaan yang sangat contrast antara kedua titik. Titik 3 mencatat velocity getaran sangat tinggi hampir pada setiap frequensi sementara pada titik 2 velocity getaran sangat rendah pada setiap domain frekuensinya. 


\section{b.Vibration characters}

Setiap getaran memiliki karakter terukur melalui gelombang sinusoidal waveform. Dibawah kita memliki sinusoidal waveform dari titik 2 dan titik 3

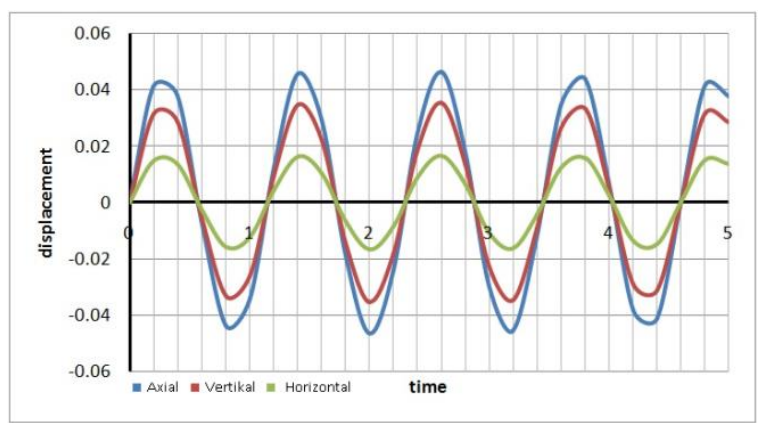

Gambar 13. Sinusoidal waveform titik 2

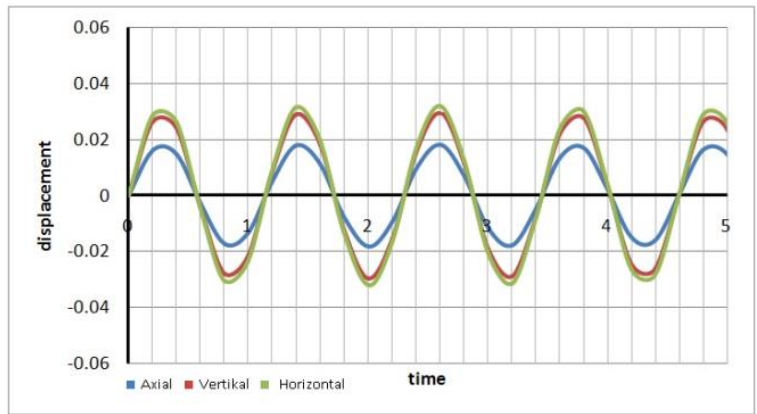

Gambar 14. Sinusoidal waveform titik 3

Dari sinusoidal waveform diketahui bahwa nilai peak to peak adalah nilai dari puncak positif ke puncak negatif sedangkan nilai peak adalah nilai dari satu puncak positif atau satu puncak negatif saja. Untuk nilai efektif atau root mean square sama dengan peak x 0,707 pada satuan waktu yang sama.

Tabel 1. Vibration Characteristic

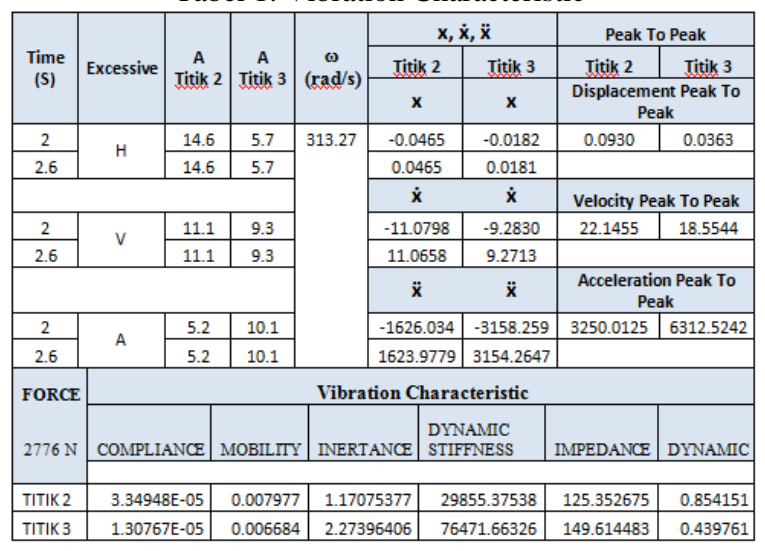

Penilaian akan sifat getaran ditentukan berdasarkan 6 aspek yang meliputi compliance, mobility, inertance, dynamic, stiffness, impedance, dan dynamic.

Perbandingan nilai compliance (displacement / force) pada titik 2 dan titik 3 adalah 5:2 per satuan newton dengan compliance titik $2>$ compliance titik 3 . Perbandingan nilai mobility (velocity / force) pada titik 2 dan titik 3 adalah 16:13 per satuan newton dengan mobility titik $2>$ mobility titik 3. Perbandingan nilai inertance ( acceleration / force) pada titik 2 dan titik 3 adalah 1:2 per satuan 
newton dengan inertance titik $2<$ inertance titik 3 . Perbandingan nilai dynamic stiffness $(1 /$ compliance) pada titik 2 dan titik 3 adalah 2:5 dengan dynamic stiffness titik $2<$ dynamic stiffness titik 3. Perbandingan nilai impedance $=(1 /$ mobility $)$ pada titik 2 dan titik 3 adalah 4:5 dengan impedance titik $2<$ impedance titik 3 . Perbandingan nilai dynamic $=(1 /$ inertance $)$ pada titik 2 dan titik 3 adalah 2:1 dengan dynamic titik $2<$ dynamic titik 3.

\section{c.Mechanichal failure diagnose}

Dirujuk melalui ISO 10186 dan ISO 2372 kita dapat mendeteksi gejala awal yang terjadi pada mesin adalah sebagai berikut,

Tabel 2. Kegagalan titik 2

\begin{tabular}{|c|c|c|c|c|c|}
\hline EXCESSIVE & \begin{tabular}{|l|}
$\mathrm{MIN}$ \\
$\mathrm{mm} / \mathrm{sec}$
\end{tabular} & \begin{tabular}{|l|} 
MAX \\
$\mathrm{mm} / \mathrm{sec}$
\end{tabular} & $\begin{array}{l}\text { AVERAGE } \\
\mathrm{mm} / \mathrm{sec}\end{array}$ & STATUS & DLAGNOSE \\
\hline $\mathrm{H}$ & 4.48 & 14.62 & 5.72 & $\begin{array}{l}\text { NO } \\
\text { (GOOD- } \\
\text { SATISFACTORY) }\end{array}$ & \multirow{3}{*}{ MISSALIGNMENT } \\
\hline $\mathrm{v}$ & 6.27 & 17.55 & 9.31 & $\begin{array}{l}\text { YES } \\
\text { (UNSATISFACTORY- } \\
\text { UNACCEPTABLE) }\end{array}$ & \\
\hline A & 1.81 & 17.55 & 10.08 & $\begin{array}{l}\text { YES } \\
\text { (UNSATISFACTORY- } \\
\text { UNACCEPTABLE) }\end{array}$ & \\
\hline
\end{tabular}

\begin{tabular}{|c|c|c|c|c|c|}
\hline EXCESSIVE & $\begin{array}{l}\mathrm{MIN} \\
\mathrm{mm} / \mathrm{sec}\end{array}$ & $\begin{array}{l}\text { MAX } \\
\text { mm/sec }\end{array}$ & $\begin{array}{l}\text { AVERAGE } \\
\mathrm{mm} / \mathrm{sec}\end{array}$ & STATUS & DLAGNOSE \\
\hline $\mathrm{H}$ & 7.02 & 21.74 & 14.63 & $\begin{array}{l}\text { YES } \\
\text { (UNSATISFACTORY- } \\
\text { UNACCEPTABLE) }\end{array}$ & \multirow{3}{*}{ LOOSENESS } \\
\hline $\mathrm{v}$ & 7.05 & 17.01 & 11.13 & $\begin{array}{l}\text { TES } \\
\text { (UNSATISFACTORY- } \\
\text { UNACCEPTABLE) } \\
\end{array}$ & \\
\hline A & 3.70 & 21.74 & 5.25 & $\begin{array}{l}\text { NO (GOOD- } \\
\text { SATISFACTORY) }\end{array}$ & \\
\hline
\end{tabular}

Berdasarkan ISO 2372 status NO sama dengan level good - satisfactory $(0 \mathrm{~mm} / \mathrm{sec} \leq \mathrm{x}<7.1$ $\mathrm{mm} / \mathrm{sec}$ ) dalam ISO 10183 sedangkan status YES sama dengan unsatisfactory - unacceptable (7.1 $\mathrm{mm} / \mathrm{sec} \leq \mathrm{x}<\infty \mathrm{mm} / \mathrm{sec})$.

Pada gambar diatas telah ditampilkan nilai minimum, maksimum, dan rata-rata kecepatan getaran yang telah diperoleh dengan pemantauan vibrasi.

Pada beberapa kondisi nilai maksimum bisa saja sangat tinggi namun nilai rata-rata kecepatan berada di level yang baik atau rendah, hal ini tentunya disebabkan oleh frekuensi data kecepatan maksimum jauh lebih kecil daripada frekuensi data kecepatan minimum sehngga menyebabkan nilai rata-rata yang kecil. Hal seperti ini dapat dilihat pada sumbu aksial titik 2 dan sumbu horizontal titik 3.

\section{d. Perpindahan kompresor dalam 3D}

Kompresor mengalami perpindahan yang sangat kecil ketika terjadi getaran , melalui ploting 3 dimensi kita dapat melihat arah dan besaran perpindahan poros kompresor.

Kita akan melakukan plotting 3D pada MATLAB dengan rumus sebagai berikut :

$>\mathrm{t}=0: 0.25: 20$

$>\mathrm{X}=0.04661 * \sin (14.63 * \mathrm{t}) ; \mathrm{Y}=0.0354 * \sin (11.13 * \mathrm{t}) ; \mathrm{Z}=0.0168 * \sin (5.25 * \mathrm{t})$

>>plot3(X,Y,Z) 


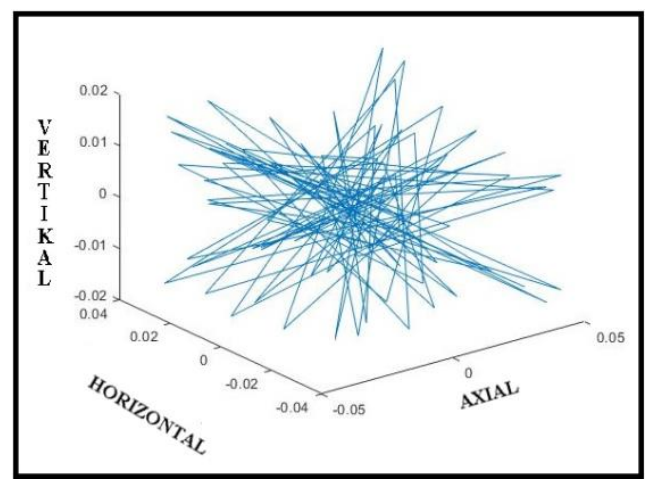

Gambar Displacement Pada Titik 2

$>\mathrm{t}=0: 0.25: 20$

$>\mathrm{X}=0.0182 * \sin (5.72 * \mathrm{t}) ; \mathrm{Y}=0.0297 * \sin (9.31 * \mathrm{t}) ; \mathrm{Z}=0.0322 * \sin (10.08 * \mathrm{t})$

$>>\operatorname{plot} 3(\mathrm{X}, \mathrm{Y}, \mathrm{Z})$

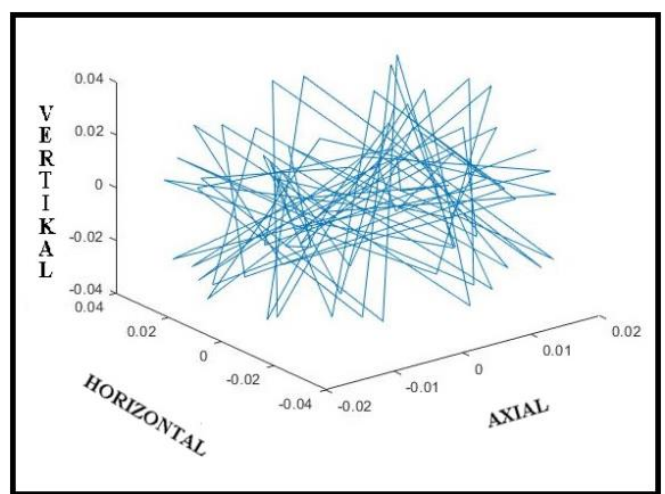

Gambar Displacement Pada Titik 3

Gambar menunjukkan perubahan displacement titik 2 berdasar pada tiga sumbu pengukuran sekaligus. Grafik bergerak dengan domain waktu yang mana pergerakan dicatat atau digambarkan dengan fungsi [ $>\mathrm{t}=0: 0.25: 20 ;]$ artinya setiap perubahan displacement dicatat dalam rentang waktu 20 sekon dengan 4 tangkapan persekonnya .

Gambar 4.26 masih sama dengan gambar 4.25 yang merupakan penggambaran displacement berdasarkan tiga sumbu sekaligus dengan domain waktu.

\section{Kesimpulan}

Setelah dilakukan penelitian tentang kerusakan kompressor turbin gas pada PT. PLN (persero) sektor pembangkitan belawan dengan pendekatan condition based maintenanced menggunakan metode fast fourrier transform maka dapat diambil kesimpulannya sebagai berikut:

1. Hasil pengukuran vibrasi pada Kompresor Titik 2 tercatat dalam range sebesar $7.02 \mathrm{~mm} / \mathrm{sec}-$ $21.74 \mathrm{~mm} / \mathrm{sec}$ dengan rata-rata getaran pada $14.63 \mathrm{~mm} / \mathrm{sec}$ untuk arah horizontal, $7.05 \mathrm{~mm} / \mathrm{sec}$ $17.01 \mathrm{~mm} / \mathrm{sec}$ dengan rata-rata getaran pada $11.13 \mathrm{~mm} / \mathrm{sec}$ untuk arah vertical dan $3.7 \mathrm{~mm} / \mathrm{sec}$ $21.74 \mathrm{~mm} / \mathrm{sec}$ dengan rata-rata getaran pada $5.2 \mathrm{~mm} / \mathrm{sec}$ untuk arah axial. Tercatat nilai peak to peak sebesar $0.036308 \mathrm{~mm}$ pada sumbu horizontal, $0.05924 \mathrm{~mm}$ pada sumbu vertical, dan $0.064336 \mathrm{~mm}$ pada sumbu aksial. Karakteristik kerusakan pada titik 2 adalah kerusakan 
Mehanical looseness. Kerusakan ini terdeteksi karena munculnya sinyal amplitude tinggi pada arah horizontal dan vertical sedangkan tidak muncul di arah axial ( ISO 10816, ISO 2372 ).

2. Hasil pengukuran vibrasi pada Kompresor Titik 3 tercatat dalam range sebesar $4.48 \mathrm{~mm} / \mathrm{sec}-$ $14.62 \mathrm{~mm} / \mathrm{sec}$ dengan rata-rata getaran pada $5.7 \mathrm{~mm} / \mathrm{sec}$ untuk arah horizontal, $6.27 \mathrm{~mm} / \mathrm{sec}$ $17.55 \mathrm{~mm} / \mathrm{sec}$ dengan rata-rata getaran pada $9.31 \mathrm{~mm} / \mathrm{sec}$ untuk arah vertical dan $1.81 \mathrm{~mm} / \mathrm{sec}-$ $17.55 \mathrm{~mm} / \mathrm{sec}$ dengan rata-rata getaran pada $10.08 \mathrm{~mm} / \mathrm{sec}$ untuk arah axial. Tercatat nilai peak to peak sebesar $0.093001 \mathrm{~mm}$ pada sumbu horizontal, $0.070706 \mathrm{~mm}$ pada sumbu vertical, dan $0.033442 \mathrm{~mm}$ pada sumbu aksial. Karakteristik kerusakan pada titik 3 adalah kerusakan Misalignment. Kerusakan ini terdeteksi karena munculnya sinyal amplitude tinggi pada arah vertical dan axial sedangkan tidak muncul di arah horizontal (ISO 10816, ISO 2372 ).

\section{Daftar pustaka}

Fariha, Aidil Othman. Vibration Analysis for Diagnostic of Local Faults in Rolling Element Bearing. Thesis. Universiti Teknikal Malaysia Melaka. 2008.

Kapidzic, Z., H. Ansell, J. Schon and K. Simonsson. Fatigue bearing failure of CFRP composite in biaxially loaded bolted joints at elevated temperature. Composite Structures. 2015; 127: 298-307.

Lian, X., M. J. Zuo and M. R. Hoseini. Vibration Signal Modeling of a Planetary Gear Set for Tooth Crack Detection. Engineering Failure Analysis. 2015; 48: 185-200.

Purnama, A. dan Ariosuko. Analisis Perbandingan Sifat Fisis dan Mekanis Bantalan Peluru Baru, Telah Dipakai dan Rusak untuk Kendaraan Bermotor Roda Dua. SINERGI. 2014; 18 (2): 92-98.

SKF, 2016, Rolling Bearings in Paper Machines.

Suhardjono, 2004, Analisis Sinyal Getaran untuk Menentukan Jenis dan Tingkat Kerusakan Bantalan Bola (Ball Bearing), Jurnal Teknik Mesin, Vol. 6, No. 2, Hal. 39-48.

V. Wowk, Machinery Vibration, New York :McGraw-Hill,Inc., 1991 